\title{
DEVELOPMENT OF EFFECTIVE TECHNOLOGIES FOR WASTE PROCESSING OF THE FOOD INDUSTRY
}

\author{
Kuzmin O. V., Isaienko V. M.
}

\section{INTRODUCTION}

Actuality of theme. Mankind faces global challenges related to climate change, environmental pollution ${ }^{1}$, food security ${ }^{2}$, which requires the solution of ecological, social, political and economic problems ${ }^{3}$.

\footnotetext{
${ }^{1}$ Barik D. Chapter 3: Energy Extraction From Toxic Waste Originating From Food Processing Industries. Energy from Toxic Organic Waste for Heat and Power Generation. 2019. P. 17-42.

Bee S.L., Hamid Z.A.A. Hydroxyapatite derived from food industry bio-wastes: Syntheses, properties and its potential multifunctional applications. Ceramics International. № 46 (11). P. A1. 2020. P. 17149-17175.

Singh R.S., Kaur N., Kennedy J.F. Pullulan production from agro-industrial waste and its applications in food industry: A review. Carbohydrate Polymers. № 2171. 2019. P. 46-57.

Garre A., Ruiz M.C., Hontoria E. Application of Machine Learning to support production planning of a food industry in the context of waste generation under uncertainty. Operations Research Perspectives. № 7.2020 .
}

Galanakis C. 11: Food waste valorization opportunities for different food industries. The Interaction of Food Industry and Environment. 2020. P. 341-422.

Lang L., Wang Y., Chen X., Zhang Z., Han W. Awareness of food waste recycling in restaurants: evidence from China. Resources, Conservation and Recycling. № 161. 2020.

Fan H., Zhang M., Bhandari B., Yang C.H. Food waste as a carbon source in carbon quantum dots technology and their applications in food safety detection. Trends in Food Science \& Technology. № 95. 2020. P. 86-96.

${ }^{2}$ Lang L., Wang Y., Chen X., Zhang Z., Han W. Awareness of food waste recycling in restaurants: evidence from China. Resources, Conservation and Recycling. № 161. 2020.

Fan H., Zhang M., Bhandari B., Yang C.H. Food waste as a carbon source in carbon quantum dots technology and their applications in food safety detection. Trends in Food Science \& Technology. № 95. 2020. P. 86-96.

Mo W.Y., Man Y.B., Wong M.H. Use of food waste, fish waste and food processing waste for China's aquaculture industry: Needs and challenge. Science of The Total Environment. 613-6141. 2018. P. 635-643.

Wiel B.Z., Weijma J., Middelaar C.E., Kleinke M., Wichern F. Restoring nutrient circularity: A review of nutrient stock and flow analyses of local agro-food-waste systems. Resources, Conservation and Recycling. № 160.2020.

${ }^{3}$ Singh R.S., Kaur N., Kennedy J.F. Pullulan production from agro-industrial waste and its applications in food industry: A review. Carbohydrate Polymers. № 2171. 2019. P. 46-57.

Lang L., Wang Y., Chen X., Zhang Z., Han W. Awareness of food waste recycling in restaurants: evidence from China. Resources, Conservation and Recycling. № 161. 2020.

Wiel B.Z., Weijma J., Middelaar C.E., Kleinke M., Wichern F. Restoring nutrient circularity: A review of nutrient stock and flow analyses of local agro-food-waste systems. Resources, Conservation and Recycling. № 160.2020 .

Tavill G. Industry challenges and approaches to food waste. Physiology \& Behavior. № 2231. 2020.

Hall G.M., Howe J. Energy from waste and the food processing industry. Process Safety and Environmental Protection. № 90 (3). 2012. P. 203-212.

Tekler Z.D., Low R., Chung S.Y., Low J.S.C., Blessing L. A Waste Management Behavioural Framework of Singapore’s Food Manufacturing Industry using Factor Analysis. Procedia CIRP. № 80. 2019. P. 578-583.

Okumus B., Taheri B., Giritlioglu I., Gannon M.J. Tackling food waste in all-inclusive resort hotels. International Journal of Hospitality Management. № 88. 2020.

Garcia-Garcia G., Stone J., Rahimifard S. Opportunities for waste valorisation in the food industry A case study with four UK food manufacturers. Journal of Cleaner Production. 21120. 2019. P. 1339-1356. 
Today, there is a deep understanding of the consequences of environmental pollution by food waste, so there is great interest in promoting "green technologies" ". In food production, only $70 \%$ of raw materials end up in the finished product, while $30 \%$ of raw materials are converted into waste and not processed at all $^{5}$. Most of them are organic wastes ${ }^{6}$ that are rich in nutrients ${ }^{7}$ and can be used as raw materials ${ }^{8}$ by other enterprises, most of the wastes end up in landfills and dumps.

With the increase in food consumption, the amount of waste increases ${ }^{9}$, which requires an increase in the area for their disposal, given the limited space for landfills and increasing the requirements of regulatory documentation for waste disposal.

Waste reduction is a key challenge for the sustainable development of the food industry ${ }^{10}$, so reducing it is a pressing issue for most businesses in the industry ${ }^{11}$. Waste recycling and utilization is a strategic goal for each

Fujii H., Kondo Y. Decomposition analysis of food waste management with explicit consideration of priority of alternative management options and its application to the Japanese food industry from 2008 to 2015. Journal of Cleaner Production. № 1881. 2018. P. 568-574.

${ }^{4}$ Hall G.M., Howe J. Energy from waste and the food processing industry. Process Safety and Environmental Protection. № 90 (3). 2012. P. 203-212.

${ }^{5}$ Schaub S.M., Leonard J.J. Composting: An alternative waste management option for food processing industries. Trends in Food Science \& Technology. № 7 (8). 1996. P. 263-268.

${ }^{6}$ Pantaleo A.M., Fordham J., Oyewunmi O.A., De Palma P., Markides C.N. Integrating cogeneration and intermittent waste-heat recovery in food processing: Microturbines vs. ORC systems in the coffee roasting industry. Applied Energy. № 2251. 2018. P. 782-796.

${ }^{7}$ Barik D. Chapter 3: Energy Extraction From Toxic Waste Originating From Food Processing Industries. Energy from Toxic Organic Waste for Heat and Power Generation. 2019. P. 17-42.

Singh R.S., Kaur N., Kennedy J.F. Pullulan production from agro-industrial waste and its applications in food industry: A review. Carbohydrate Polymers. № 2171. 2019. P. 46-57.

Mo W.Y., Man Y.B., Wong M.H. Use of food waste, fish waste and food processing waste for China's aquaculture industry: Needs and challenge. Science of The Total Environment. 613-6141. 2018. P. 635-643.

Wiel B.Z., Weijma J., Middelaar C.E., Kleinke M., Wichern F. Restoring nutrient circularity: A review of nutrient stock and flow analyses of local agro-food-waste systems. Resources, Conservation and Recycling. № 160. 2020.

${ }^{8}$ Amorim C.D., Camilo A.G., de Oliveira C., Petenucci M.E., Fonseca G.G. Turning pork processing waste into value-added chemicals for the food industry. Sustainable Materials and Technologies. № 6. 2015. P. $1-5$.

${ }_{9}^{9}$ Martin-Rios C., Demen-Meier C., Gussling S., Cornuz C. Food waste management innovations in the foodservice industry. Waste Management. № 79. 2018. P. 196-206.

${ }_{10}$ Barik D. Chapter 3: Energy Extraction From Toxic Waste Originating From Food Processing Industries. Energy from Toxic Organic Waste for Heat and Power Generation. 2019. P. 17-42.

Tekler Z.D., Low R., Chung S.Y., Low J.S.C., Blessing L. A Waste Management Behavioural Framework of Singapore’s Food Manufacturing Industry using Factor Analysis. Procedia CIRP. № 80. 2019. P. 578-583.

Martin-Rios C., Demen-Meier C., Gцssling S., Cornuz C. Food waste management innovations in the foodservice industry. Waste Management. № 79. 2018. P. 196-206.

${ }^{11}$ Garre A., Ruiz M.C., Hontoria E. Application of Machine Learning to support production planning of a food industry in the context of waste generation under uncertainty. Operations Research Perspectives. № 7.2020.

Tavill G. Industry challenges and approaches to food waste. Physiology \& Behavior. № 2231. 2020.

Hall G.M., Howe J. Energy from waste and the food processing industry. Process Safety and Environmental Protection. № 90 (3). 2012. P. 203-212.

Okumus B., Taheri B., Giritlioglu I., Gannon M.J. Tackling food waste in all-inclusive resort hotels. International Journal of Hospitality Management. № 88. 2020. 
company $^{12}$, which involves the involvement of innovative technologies ${ }^{13}$ based on the evaluation of decisions in reducing the cost of finished products, minimizing raw material losses, increasing the yield of finished products ${ }^{14}$. The practical implementation of innovative measures allows to establish relationships between processes and technologies of food industry processing and provides an opportunity to form the main provisions in the field of waste management ${ }^{15}$.

Despite the importance of this issue for the world community in the food industry, the connection between efficient resource-saving and environmental technologies of waste processing, disposal of by-products in the scientific literature is given limited attention ${ }^{16}$. Extensive knowledge was brought by foreign scientists who devoted their work to the processing of food industry waste into biofuels, biogas, biopolymers, biofertilizers ${ }^{17}$, bioceramic materials $^{18}$, sorbents ${ }^{19}$.

Fujii H., Kondo Y. Decomposition analysis of food waste management with explicit consideration of priority of alternative management options and its application to the Japanese food industry from 2008 to 2015. Journal of Cleaner Production. № 1881. 2018. P. 568-574.

${ }^{12}$ Galanakis C. 11: Food waste valorization opportunities for different food industries. The Interaction of Food Industry and Environment. 2020. P. 341-422.

Lang L., Wang Y., Chen X., Zhang Z., Han W. Awareness of food waste recycling in restaurants: evidence from China. Resources, Conservation and Recycling. № 161. 2020.

Garcia-Garcia G., Stone J., Rahimifard S. Opportunities for waste valorisation in the food industry A case study with four UK food manufacturers. Journal of Cleaner Production. 21120. 2019. P. 1339-1356.

Fujii H., Kondo Y. Decomposition analysis of food waste management with explicit consideration of priority of alternative management options and its application to the Japanese food industry from 2008 to 2015. Journal of Cleaner Production. № 1881. 2018. P. 568-574.

${ }^{13}$ Garre A., Ruiz M.C., Hontoria E. Application of Machine Learning to support production planning of a food industry in the context of waste generation under uncertainty. Operations Research Perspectives. № 7.2020.

${ }^{14}$ Tekler Z.D., Low R., Chung S.Y., Low J.S.C., Blessing L. A Waste Management Behavioural Framework of Singapore's Food Manufacturing Industry using Factor Analysis. Procedia CIRP. № 80. 2019. P. 578-583.

${ }^{15}$ Mo W.Y., Man Y.B., Wong M.H. Use of food waste, fish waste and food processing waste for China's aquaculture industry: Needs and challenge. Science of The Total Environment. 613-6141. 2018. P. 635-643.

${ }^{16}$ Martin-Rios C., Demen-Meier C., Gussling S., Cornuz C. Food waste management innovations in the foodservice industry. Waste Management. № 79. 2018. P. 196-206.

17 Barik D. Chapter 3: Energy Extraction From Toxic Waste Originating From Food Processing Industries. Energy from Toxic Organic Waste for Heat and Power Generation. 2019. P. 17-42.

${ }^{18}$ Bee S.L., Hamid Z.A.A. Hydroxyapatite derived from food industry bio-wastes: Syntheses, properties and its potential multifunctional applications. Ceramics International. № 46 (11). P. A1. 2020. P. 17149-17175.

${ }^{19}$ Landin-Sandoval V.J., Mendoza-Castillo D.I., Bonilla-Petriciolet A., Aguayo-Villarreal I.A., GonzalezPonce H.A. Valorization of agri-food industry wastes to prepare adsorbents for heavy metal removal from water. Journal of Environmental Chemical Engineering. № 8 (5). 2020.

Kuzmin O., Shendrik T. Prospective assessment of the use of the carbonized wood waste of food industry for the production of activated carbon. Food Science for Well-being (CEFood 2016) : 8th Central European Congress on Food., Kyiv, 23-26 May 2016. Kyiv, 2016. P. 109.

Kuzmin O., Shendrik T., Zubkova V. Substantiation of the conditions of obtaining porous carbon materials from pyrolyzed wood wastes by chemical activation of $\mathrm{H}_{3} \mathrm{PO}_{4}$. Ukrainian Food Journal. 2017. № 6 (1). P. 103-116.

Kuzmin O., Tamarkina J., Shendrik T., Zubkova V., Koval O., Roman T. Production of active coal from pyrolyzed wood wastes by alkaline activation of KOH. Ukrainian Food Journal. 2017. № 6 (3). P. 443-458. 


\section{Characteristics of food industry waste}

In the process of frying with smoke and smoking, numerous substances are formed, which are contained in the smoke during incomplete combustion of wood, which enter the product and provide its preservation, flavoring and desired color. Technological properties of smoke depend on its chemical composition and, above all, on the degree of saturation with aromatic substances.

The formation of pyrolyzed wood waste in the process of generating airsmoke mixture ${ }^{20}$ involves the use of wood chips ${ }^{21}$ of hardwoods (beech, alder, oak, elm, linden, hazel, maple, etc.), as well as stone species (cherry, cherry, apple, apricot, plum, etc.).

One of the most common species is oak ${ }^{22}$, which has a positive effect on the composition and concentration of active smoking agents during smoke smoking and reduces tar formation and increases the organoleptic characteristics of meat, sausages, cheese, fish and other foods, resulting in pyrolyzed wood waste with incomplete combustion of wood.

Wood chips is obtained by grinding wood in the form of oblique parallelepipeds with an acute angle in the range of $30-60^{\circ}$, the specified size fractions: large size $-6 \times 12 \times 3 \mathrm{~mm}$; medium size $-4 \times 6 \times 3 \mathrm{~mm}$; small size 1-3 mm; very small size $-0.3-1.0 \mathrm{~mm}^{23}$. The use of technological chips of large fractions of $6 \times 12 \times 3 \mathrm{~mm}$, with a mass fraction of chips residues on sieves with holes with a diameter of $30 \mathrm{~mm}$ - not more than $3 \%, 20$ and $10 \mathrm{~mm}-$ not less than $86 \%, 5 \mathrm{~mm}$ - not more than $10 \%$, on the pallet - no more than $1 \%$, positively affects the formation of liquid and gaseous substances $60-70 \%$ when receiving pyrolyzed chips $30-40 \%{ }^{24}$.

The size of wood chips fractions affects the profile of its application, depending on the smoking temperature: cold $-279-295 \mathrm{~K}$, hot $-303-323 \mathrm{~K}$, high temperature - 353-373 K, as well as the method of generating air-smoke

Кузьмин О.В., Тамаркина Ю.В., Шендрик Т.Г. Перспективы использования древесных отходов пищевой промышленности для получения адсорбентов. Актуальные вопросы охраны окружающей среды и обеспечения экологической безопасности промышленных регионов : материалы междунар. науч.-практ. конф., г. Кемерово, 3-4 октябр. 2017 г. Кемерово, 2017. С. 295-301.

Kuzmin A., Kuzmin O., Shendrik T. Obtaining and properties of active charcoal from pyrolized wood waste. Chemical Technology and Engineering: 2nd International Scientific Conference, Lviv, 24-28 June 2019. Lviv. P. 87-89.

${ }^{20}$ Кузьмин О.В., Тамаркина Ю.В., Шендрик Т.Г. Перспективы использования древесных отходов пищевой промышленности для получения адсорбентов. Актуальные вопросы охраны окружающей среды и обеспечения экологической безопасности промышленных регионов : материалы междунар. науч.-практ. конф., г. Кемерово, 3-4 октябр. 2017 г. Кемерово, 2017. С. 295-301.

${ }^{21}$ Kuzmin O., Shendrik T. Prospective assessment of the use of the carbonized wood waste of food industry for the production of activated carbon. Food Science for Well-being (CEFood 2016) : 8th Central European Congress on Food., Kyiv, 23-26 May 2016. Kyiv, 2016. P. 109.

${ }^{22}$ Kuzmin A., Kuzmin O., Shendrik T. Obtaining and properties of active charcoal from pyrolized wood waste. Chemical Technology and Engineering: 2nd International Scientific Conference, Lviv, 24-28 June 2019. Lviv, P. 87-89.

${ }^{23}$ Спосіб виробництва піролізованої тріски: пат. 102045 Україна: МПК С12G 3/07. № u201504113; заяв. 28.04.2015; опубл. 12.10.2015, Бюл. № 19.

${ }^{24}$ Спосіб обробки деревини дуба для одержання піролізованої тріски: пат. 115673 Україна: МПК C12G 3/07, С12Н 1/22, А23В 4/044. № а201504104; заяв. 28.04.2015; опубл. 11.12.2017, Бюл. № 21. 
mixture at pyrolysis temperature: smoke smoldering - 573-773 K; smoke friction - 593-653 K; smoke condensate - 593-653 K; smoke distillate from $573 \mathrm{~K}$.

Smoke decay is the most common method of generating an air-smoke mixture, which is formed by flameless combustion of a thick layer of wood chips with an initial mass fraction of moisture of $8-12 \%$, moistened before pyrolysis with drinking water to $35-65 \%$, at a pyrolysis temperature of $573-773 \mathrm{~K}$, with a small amount of air and constant stirring ${ }^{25}$.

Table 1 shows the conditions for obtaining an air-smoke mixture.

Table 1

Terms of use of air-smoke mixture

\begin{tabular}{|l|c|c|c|c|c|c|}
\hline \multirow{2}{*}{ Product name } & \multicolumn{2}{|c|}{ Roasting with smoke } & \multicolumn{5}{c|}{ Smoking } \\
\cline { 2 - 7 } & $T, \mathrm{~K}$ & $\tau, \mathrm{s} \cdot 60^{2}$ & $T, \mathrm{~K}$ & $W, \%$ & $\mathrm{v}, \mathrm{m} / \mathrm{s}$ & $\tau, \mathrm{s} \cdot 60^{2}$ \\
\hline Boiled sausages & $338-348$ & $0.50-1.17$ & & & & \\
\hline $\begin{array}{l}\text { Semi-smoked } \\
\text { sausages }\end{array}$ & $338-348$ & $0.83-1.17$ & $308-323$ & $60-65$ & 1.0 & $6-12$ \\
\hline $\begin{array}{l}\text { Smoked and cooked } \\
\text { poultry products }\end{array}$ & 363 & 1.00 & $298-303$ & & & $\begin{array}{c}\text { until color } \\
\text { appears }\end{array}$ \\
\hline $\begin{array}{l}\text { Raw smoked and } \\
\text { cured sausages }\end{array}$ & & & $291-295$ & $74-80$ & $0.2-0.5$ & $24-48$ \\
\hline
\end{tabular}

Wood chips should have an initial humidity of $8-12 \%$, because at a humidity of more than $12 \%$ in the wood is formed pathogenic microflora and products of its metabolism, and the use of wood chips with a moisture content of less than $8 \%$ is not economically feasible, which leads to additional energy consumption during drying and storage ${ }^{26}$.

Before pyrolysis, wood chips is moistened with drinking water up to $35-65 \%$. At a humidity of more than $65 \%$ there is a decrease in the mass concentration of phenols and an increase in the mass concentration of aldehydes and acids in the air-smoke mixture, which lead to an acidic taste in the finished product. When the humidity of the chips is less than $35 \%$ there is a low smoke with a simultaneous increase in the pyrolysis temperature ${ }^{27}$.

Heating wood to a temperature above $573 \mathrm{~K}$ leads to its destruction pyrolysis. At a smoldering temperature below $623 \mathrm{~K}$, phenols and aldehydes are not sufficiently released in the smoke, which leads to a weak taste, aroma and color of products after smoking. The decay temperature of more than

\footnotetext{
${ }^{25}$ Спосіб виробництва піролізованої тріски: пат. 102045 Україна: МПК С12G 3/07. № u201504113; заяв. 28.04.2015; опубл. 12.10.2015, Бюл. № 19.

Спосіб обробки деревини дуба для одержання піролізованої тріски: пат. 115673 Україна: МПК C12G 3/07, С12Н 1/22, А23В 4/044. № а201504104; заяв. 28.04.2015; опубл. 11.12.2017, Бюл. № 21.

${ }^{26}$ Спосіб виробництва пористих вуглецевих матеріалів із піролізованих деревних відходів: пат. 103581 Україна: МПК С01В 31/08. № u201505455; заяв. 03.06.2015; опубл. 25.12.2015, Бюл. № 24.

${ }^{27}$ Спосіб виробництва активного вугілля із карбонізату деревини: пат. 102942 Україна, МПК С01В 31/10. № u201505202; заяв. 27.05.2015; опубл. 25.11.2015, Бюл. № 22.
} 
$773 \mathrm{~K}$ leads to the decomposition of smoking substances, an increase in the content of 3.4-benzpyrene, which distorts the taste and smell of the finished product, as well as leads to toxicological hazards. Therefore, the decay temperature should be maintained at $573-773 \mathrm{~K}^{28}$.

The supply of air leads to an increase in combustion products and in general to an improvement in the taste of the final product, and the lack of mixing of chips during pyrolysis leads to compaction of the surface layer of pyrolyzate and unregulated temperature inside; as a result there can be the centers of an open flame with a temperature to $1273 \mathrm{~K}$.

The pyrolysis time of wood chips depends on the conditions of heat treatment of meat, sausage products, cheese, fish and other food products, which due to frying with smoke or smoking last for $0.5-48.0$ hours. So cooked sausages are fried with smoke for 30-70 minutes, and smoked and cured sausages are smoked for $1-2$ days $^{29}$.

\section{Characteristics of wood for the production of alcoholic beverages}

Together with the scientifically sound selection of oak ridge in the forest, the process of drying-ripening of clapboard plays an important role ${ }^{30}$. Natural drying-maturation of oak clapboard for three years helps to increase the concentration of whiskey lactones by 4.11 times more than with artificial drying; vanillin - 4.63 times; syringaldehyde - 4.47 times; eugenol 2.7 times. The concentration of phenolic substances in the extract from the clapboard of natural drying is 1.45 times, and the dry extract is 1.16 times less than in artificial drying ${ }^{31}$.

The degree of grinding of oak wood (clapboard, micro- clapboard, wood chips and micro-wood chips) affects the rate of aging of wines and cognac alcohols $^{32}$. The differences in the speed of the process of aging cognac alcohol are based on various features of its impregnation in the layers of wood - in the surface layers of oak wood in the inner surface of barrels, clapboards and

\footnotetext{
${ }^{28}$ Спосіб виробництва активного вугілля із карбонізату деревини: пат. 112819 Україна: МПК С01В 31/08. № а201505195; заяв. 27.05.2015; опубл. 25.10.2016, Бюл. № 20.

${ }^{29}$ Спосіб виробництва піролізованої тріски: пат. 102045 Україна: МПК C12G 3/07. № u201504113; заяв. 28.04.2015; опубл. 12.10.2015, Бюл. № 19.

Спосіб обробки деревини дуба для одержання піролізованої тріски: пат. 115673 Україна: МПК C12G 3/07, С12Н 1/22, А23В 4/044. № а201504104; заяв. 28.04.2015; опубл. 11.12.2017, Бюл. № 21.

30 Луканин А., Зражва С. Сушка и созревание дубовой клепки. Напитки. Технологии. Инноващии. 2013. № 8. С. 82-83.

Луканін О.С., Тимчик О.В., Зражва С.Г. Мікробіологічна оцінка деревини дуба різних регіонів України. Агроекологічний журнал. 2008. № 3. С. 157-160.

Рекомендації щодо технології висушування-дозрівання дубової клепки для винних, коньячних та кальвадосних бочок / Луканін О.С. та ін. Київ : Інститут агроекології і природокористування НААН, 2010.56 c.

Vivas N. Manuel de tonnellerie a l'usage des utilisateurs de futaille. Editions Feret. Bordeaux. 2002. 207 р.; Скурихин С.М. Химия коньяка и бренди. Москва : ДеЛи Принт, 2005. 296 с.

31 Луканин А., Зражва С. Сушка и созревание дубовой клепки. Напитки. Технологии. Инновации. 2013. № 8. C. 82-83.

32 Луканін О.С. Ефект нової бочки. Виноград і вино. 2002. № 5. С. 20-23.
} 
large pieces, or in the entire volume of wood using small fractions. These features of wood impregnation affect the processes of hydrolysis of high molecular weight substances of oak (lignin, hemicelluloses and others) to low molecular weight components (aromatic aldehydes, monosaccharides, etc.), their extraction, transformation and oxidation ${ }^{33}$.

According to the international classification, oak wood for winemaking is divided by the concentration of phenolic substances, including tannins, aromatic components: whiskey lactones (trans- and cis- $\beta$-methyl- $\gamma$-octalactone), eugenol, vanillin, scopoletin and other lignin cleavage products that form the aroma, bouquet and taste of future wines and their distillates ${ }^{34}$, giving them vanilla, spicy, caramel and other noble tones.

The specific surface area of the clapboard, which is laid in the tank for aging cognac alcohol, should be $70-90 \mathrm{~cm}^{2} / \mathrm{dm}^{3}$, which corresponds to the area of the inner surface of the barrel with a capacity of 35-60 decaliters ${ }^{35}$.

Extraction of oak components of small fractions takes place at a faster rate than in barrels and clapboard. This occurs only until the moment close to the depletion of wood, which is observed when it reaches $80 \%$ of the total content of extracted components of oak, after which - the extraction slows down sharply. The use of small fractions of oak in the amount of 7.8 and $10.4 \mathrm{~g} / \mathrm{dm}^{3}$ (based on the layer of wood on the inner surface of the barrel 1.5 and $2.0 \mathrm{~mm}$ ) led to the accumulation, respectively, $45-50$ and $70-75 \%$ of the content of oak components at 5-year aging in oak barrels. Such concentrations of oak components in alcohol are extracted from small fractions of oak after 18-24 months. Among the various fractions of crushed oak in terms of organoleptic indicators of aging of cognac alcohols, wood chips of the middle fraction is recognized as the best ${ }^{36}$.

Today there are many ways to prepare crushed oak wood for wine and brandy production ${ }^{37}$ : grinding; oxygen treatment at a pressure $(P)$ of 1.5-3.0 MPa, temperature (T) 383-393 $\mathrm{K}$, time $\tau(50-150) \cdot 60^{2} \mathrm{~s}$; grinding;

\footnotetext{
${ }^{33}$ Оганесянц Л.А. Дуб и виноделие. Москва : Пищевая промышленность, 1998. 256 с.

34 Луканин А., Зражва С. Сушка и созревание дубовой клепки. Напитки. Технологии. Инноваџии. 2013. № 8. С. $82-83$.

Луканін О.С., Сидоренко О.М. Критерії визначення віку коньячних спиртів. Вісник аграрної науки. 2016. № 10. С. 51-60.

Удосконалення технології висушування-дозрівання дубової клепки / Луканін О.С., Байлук С.I., Зражва С.Г., Агафонов М.Ф. Вісник аграрної науки. 2010. № 12. С. 52-55.

${ }^{35}$ Сборник технологических инструкций, правил и нормативных материалов по винодельческой промышленности / под ред. Г.Г. Валуйко. Москва : Агропромиздат, 1985. 512 с.

36 Луканін О.С., Сидоренко О.М., Феодосіді К.Ф. Продукти переробки дуба, або ефект «нової бочки», при витримці вин та коньячних спиртів. Сучасні напрями розвитку технології алкогольних $i$ безалкогольних напоїв : І міжнар. наук.-практ. конф. м. Київ, 2006 р. Київ, 2006. С. 4-11.

37 Луканин А., Зражва С. Сушка и созревание дубовой клепки. Напитки. Технологии. Инновации. 2013. № 8. С. 82-83.

Спосіб виробництва дубової мікроклепки : пат. 8047 Україна : МПК С12G 3/07. № u200500127 ; заявл. 05.01.2005; опубл. 15.07.2005, Бюл. № 7.

Спосіб обробки подрібненої деревини дуба : пат. 50046А Україна, МПК С12G 3/07. № 2001031730; заявл. 15.03.2001; опубл. 15.10.2002, Бюл. № 10.
} 
treatment with $\mathrm{HCl}$ solution (hydromodule 1:0.6); air treatment (T373-378 K; $\tau 0.5 \cdot 60^{2} \mathrm{~s}$ ); treatment with a solution of ammonia (hydromodule 1:0.6) with subsequent exposure to air $\tau 0.17 \cdot 60^{2} \mathrm{~s}$; grinding to the size lxbxh (20x55x4) $10^{-3} \mathrm{~m}$; enzyme treatment; drying ( $\left.T 423 \mathrm{~K} ; \tau 48 \cdot 60^{2} \mathrm{~s}\right)$ to a humidity $(W)$ of $6.0 \%$; crushing of oak wood (petiolate, rocky) aged from 80 years to the size $l(5-35) \cdot 10^{-3} \mathrm{~m}, h \leq 5 \cdot 10^{-3} \mathrm{~m}$; treatment with enzyme preparation $\tau 4 \cdot 60^{2}$ s; drying (T $423-443 \mathrm{~K}, \tau(30-36) \cdot 60^{2}$ s) to $W \leq 6 \pm 2 \%$.

Treatment of wine materials with crushed oak wood eliminates their shortcomings - the "mouse tone" disappears due to the adsorption of acetamide by wood and the transformation of substances that cause their appearance. Due to ethanolysis and extraction, the $\mathrm{pH}$ decreases, the mass concentration of phenolic substances increases. Due to adsorption, the mass concentration of volatile acids decreases. The stability of wines against colloidal turbidity increases, the stage of treatment with bentonite or activated carbon is excluded ${ }^{38}$.

One of the priority areas for alcoholic beverage and wine and cognac production is the production of crushed oak wood from pyrolyzed wood waste. The formation of pyrolyzed wood waste in the process of generating air-smoke mixture involves the use of wood chips of hardwoods - oak, which has a positive effect on the composition and concentration of smoking agents, reducing resin formation and increasing organoleptic characteristics.

The aim of the work is to determine the prospects of pyrolyzed wood waste for the production of alcoholic beverages (wine and cognac products, cognac, whiskey, calvados), as well as in the production of porous carbon materials and activated carbon.

\section{Materials and methods. Description of the experimental stand}

The process of heat treatment was carried out in a cooking-smoking thermal chamber of modular type "Jugema KWE-3" with electric heating, which is designed for heat treatment of meat products, cheeses, fish and other food products.

According to the production task for the production of semi-smoked sausage "Viennese salami" (2nd grade; natural pork casing $d(34-36) \cdot 10^{-3} \mathrm{~m}$; in shape - a horn length of $0.20-0.25 \mathrm{~m}$; the norm of pure mass of products per frame $-180 \mathrm{~kg}$ ) and technological instructions were carried out: frying with smoke - at $T_{1} 343 \mathrm{~K}, \tau_{1} 1 \cdot 60^{2} \mathrm{~s}$; smoking - when: $T_{2} 323 \mathrm{~K} ; W_{3} 62 \%$; $v_{1}$ $1 \mathrm{~m} / \mathrm{s} ; \tau_{2} 6.13 \cdot 60^{2} \mathrm{~s}$.

Wood chips were fed to the combustion chamber of the gas generator (Fig. 1) using a stirrer, which operates periodically during pyrolysis, as well as in the process of removing spent pyrolyzed wood waste. The burner was

\footnotetext{
${ }^{38}$ Кузьмин О.В., Королесова В.Г. Стабилизация вина в прочессе хранения. Актуальные проблемь современного товароведения : матер. междунар. научн.-практ. конф., г. Гомель, 18-19 нояб. 2010 г., Гомель, 2010. С. 89.

Спосіб лікування хвороби вина «мишачий тон»: пат. 72724А Україна, МПК С12G 3/07, С12Н 1/02. № 20031213183; заяв. 30.12.2003; опубл. 15.03.2005, Бюл. № 3.
} 
turned on and the wood was ignited for $\tau 180-360 \mathrm{~s}$ depending on the mass fraction of wood chips moisture. During pyrolysis, air is supplied to the combustion chamber and smoke is formed. The smoke is fed into the extraction area by a fan. To reduce the smoke temperature and counteract ignition, water is sprayed in the combustion chamber. All processes that occur during pyrolysis are controlled by microprocessor control.

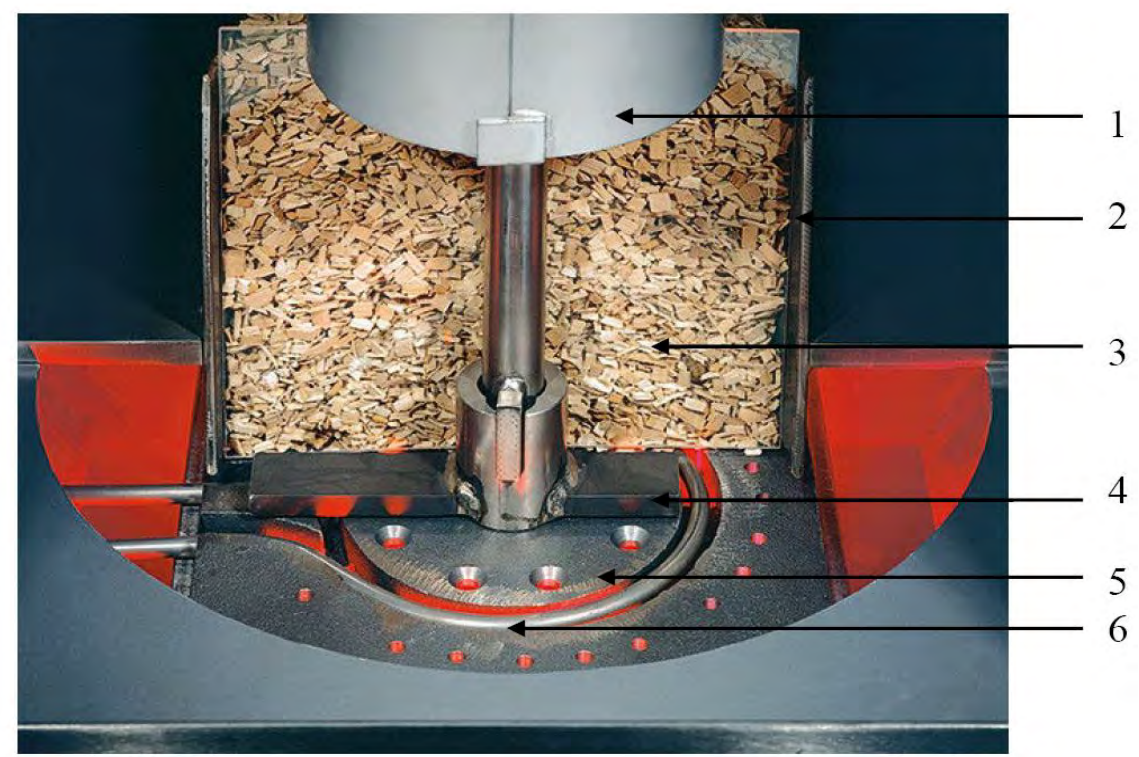

a

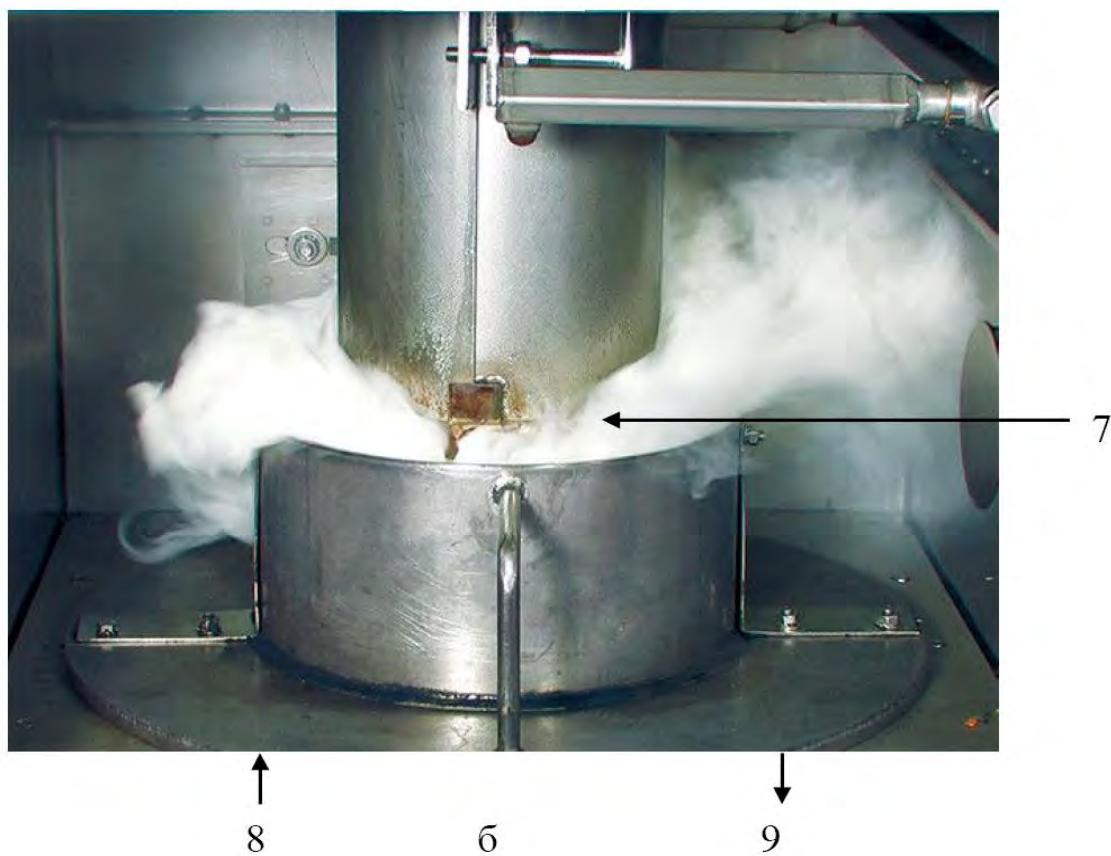

Fig. 1. Scheme of the smoke generator: a - section of the smoke generator

in preparation for pyrolysis of chips; $b$ - appearance of the smoke generator in the process of wood chips pyrolysis; 1 - wood chips hopper; 2 - casing; 3 - wood chips; 4 - mixer; 5 - grate; 6 - tubular electric heater; 7 - smoke; 8 - air; 9 - pyrolyzed wood waste 


\section{Results and discussions}

\subsection{Experimental studies}

Tables 2-4 present the conditions of the study of the processes of preparation of technological chips, the conditions of its pyrolysis and the conditions of preparation of pyrolyzed wood waste.

Table 2

Conditions for the preparation of technological wood chips

\begin{tabular}{|c|l|c|}
\hline Symbol & \multicolumn{1}{|c|}{ Name of indicator } & Characteristic \\
\hline & Type of particles by shape & wood chips \\
\hline & Type of particles by purpose & technological \\
\hline & Type of particles by type of wood & oak \\
\hline$l \times b \times h$ & Type of particles by fraction size, $\mathrm{m}$ & $(6 \times 12 \times 3) \cdot 10^{-3}$ \\
\hline & Mass fraction of wood chips residues $(\%)$ on & \\
& sieves with holes with a diameter $(\mathrm{m}):$ & 0.8 \\
& $d \geq 30 \cdot 10^{-3}$ & $(14.0 ; 80.0)$ \\
& $30 \cdot 10^{-3}>d \geq 20 \cdot 10^{-3} ; 20 \cdot 10^{-3}>d \geq 10 \cdot 10^{-3}$ & 4.9 \\
& $10 \cdot 10^{-3}>d \geq 5 \cdot 10^{-3}$ & 0.3 \\
\hline$W_{1}$ & $d<5 \cdot 10^{-3}$ & 9.42 \\
\hline \multirow{2}{*}{$W_{2}$} & Mass fraction of wood chips initial moisture, $\%$ & 49.08 \\
\hline
\end{tabular}

Table 3

Conditions of pyrolysis of technological chips

\begin{tabular}{|c|l|c|}
\hline Symbol & \multicolumn{1}{|c|}{ Name of indicator } & Characteristic \\
\hline & Type of smoking & smokes \\
\hline & Method of air-smoke mixture generation & smoke decay \\
\hline$T_{1}$ & Frying temperature with smoke, $\mathrm{K}$ & 343 \\
\hline$\tau_{1}$ & Frying time with smoke, $\mathrm{s}$ & $1 \cdot 60^{2}$ \\
\hline$T_{2}$ & Smoking temperature, $\mathrm{K}$ & 323 \\
\hline$W_{3}$ & Relative humidity in the thermal chamber, $\%$ & 62 \\
\hline$v_{1}$ & Air velocity in the thermal chamber, $\mathrm{m} / \mathrm{s}$ & 1 \\
\hline$\tau_{2}$ & Smoking time, $\mathrm{s}$ & $6.13 \cdot 60^{2}$ \\
\hline$T_{3}$ & The decay temperature (pyrolysis), $\mathrm{K}$ & 633 \\
\hline$\tau_{3}$ & Pyrolysis time, $\mathrm{s}$ & $7.13 \cdot 60^{2}$ \\
\hline$m_{\tau}$ & Mass consumption of wood chips, $\mathrm{kg} / \mathrm{s}$ & $9.20 \cdot 60^{-2}$ \\
\hline$Y_{1}$ & Yield of liquid and gaseous substances, $\%$ & 61.7 \\
\hline$Y_{2}$ & Yield ratio of pyrolyzed wood waste, $\%$ & 38.3 \\
\hline$W_{4}$ & $\begin{array}{l}\text { Mass fraction of moisture of pyrolyzed wood } \\
\text { waste, } \%\end{array}$ & 43.01 \\
\hline
\end{tabular}


Table 4

Conditions for preparation of pyrolyzed wood waste

\begin{tabular}{|c|c|c|}
\hline Symbol & Name of indicator & Characteristic \\
\hline$p H_{1}$ & Hydrogen index of acid solution, units $\mathrm{pH}$ & 2.4 \\
\hline$\tau_{4}$ & $\begin{array}{l}\text { Time of treatment of pyrolyzed wood waste with } \\
\text { acid solution, s }\end{array}$ & 300 \\
\hline$p \mathrm{H}_{2}$ & Hydrogen index of alkaline solution, units $\mathrm{pH}$ & 9.84 \\
\hline$\tau_{5}$ & $\begin{array}{l}\text { Time of treatment of pyrolyzed wood waste with } \\
\text { alkaline solution, } s\end{array}$ & 300 \\
\hline$p H_{3}$ & Hydrogen index of neutral solution, units $\mathrm{pH}$ & 6.91 \\
\hline$\tau_{6}$ & $\begin{array}{l}\text { Time of treatment of pyrolyzed wood waste with } \\
\text { a neutral solution, s }\end{array}$ & 300 \\
\hline$W_{5}$ & $\begin{array}{l}\text { Mass fraction of moisture of pyrolyzed wood } \\
\text { waste after treatment with aqueous solutions, } \%\end{array}$ & 63.50 \\
\hline$T_{4}$ & Outdoor drying temperature, $\mathrm{K}$ & 295 \\
\hline$W_{6}$ & Relative humidity, $\%$ & 74 \\
\hline$v_{2}$ & Air speed, $\mathrm{m} / \mathrm{s}$ & 1.5 \\
\hline$\tau_{7}$ & $\begin{array}{l}\text { Drying time of pyrolyzed wood waste in the open } \\
\text { air, s }\end{array}$ & $336 \cdot 60^{2}$ \\
\hline$T_{5}$ & Drying temperature in the oven, $\mathrm{K}$ & 373 \\
\hline$W_{7}$ & $\begin{array}{l}\text { Final mass fraction of moisture of pyrolyzed } \\
\text { wood waste, } \%\end{array}$ & 6.58 \\
\hline & $\begin{array}{l}\text { Mass fraction of pyrolyzed wood waste residues } \\
(\%) \text { on sieves with holes in diameter }(\mathrm{m}) \text { : } \\
\mathrm{d} \geq 5.0 \cdot 10^{-3} \\
5.0 \cdot 10^{-3}>\mathrm{d} \geq 3.6 \cdot 10^{-3} \\
3.6 \cdot 10^{-3}>\mathrm{d} \geq 1.0 \cdot 10^{-3} \\
\mathrm{~d}<1,0 \cdot 10^{-3}\end{array}$ & $\begin{array}{c}63.8 \\
20.8 \\
11.9 \\
3.5\end{array}$ \\
\hline
\end{tabular}

\subsection{Methods of experimental research}

For pyrolysis we used technological chips of hardwood species - from oak wood of large fractions - $(6 \times 12 \times 3) \cdot 10^{-3} \mathrm{~m}$; with a mass fraction of wood chips residues on sieves with holes with a diameter of: $d \geq 30 \cdot 10^{-3} \mathrm{~m}-0.8 \%$; $30 \cdot 10^{3}>d \geq 20 \cdot 10^{-3} \mathrm{~m}-14 \% ; 20 \cdot 10^{-3}>d \geq 10 \cdot 10^{-3} \mathrm{~m}-80 \% ; 10 \cdot 10^{-3}>d \geq$ $\geq 5 \cdot 10^{-3} \mathrm{~m}-4.9 \%$; on the pallet $\mathrm{d}<5 \cdot 10^{-3} \mathrm{~m}-0.3 \%$. The initial mass fraction of wood chips moisture before loading into the smoke generator was $-W_{1} 9.42 \%$. Before pyrolysis, the chips were further moistened with drinking water to a value of $W_{2} 49.08 \%$ to ensure the relative humidity in the chamber $W_{3} 62 \%$ when smoking semi-smoked sausages.

Pyrolysis was performed at a temperature of $T_{3} 633 \mathrm{~K}$ for $\tau_{3} 7.13 \cdot 60^{2} \mathrm{~s}$. The average wood chips consumption was $m_{\tau} 9.20 \cdot 60^{-2} \mathrm{~kg} / \mathrm{s}$ in the formation of pyrolyzed wood waste $-3.52 \cdot 60^{-2} \mathrm{~kg} / \mathrm{s}\left(Y_{2} 38.3 \%\right)$. That is, for the cycle of 442 
roasting with smoke and smoking $\tau_{3}$ for $7.13 \cdot 60^{2} \mathrm{~s}, 65.6 \mathrm{~kg}$ of wood chips were used and $(m) 25.1 \mathrm{~kg}$ of pyrolyzed wood waste were obtained.

In the process of pyrolysis received pyrolyzed wood waste with a mass fraction of moisture $\left(W_{4}\right) 43.01 \%$, which was treated with an aqueous solution with a $\mathrm{pH}$ of 2.4 for $\tau_{4} 300 \mathrm{~s}$, neutralized with an aqueous solution with a $\mathrm{pH}$ of 9.84 for $\left(\tau_{5}\right) 300 \mathrm{~s}$, adjusted the $p H$ with an aqueous solution with a $p H$ of 6.91 for $\left(\tau_{6}\right) 300 \mathrm{~s}$.

Drying of pyrolyzate with mass fraction of moisture $W_{5} 63.50 \%$ during $\tau_{7}$ $336 \cdot 60^{2} \mathrm{~s}$ outdoors $\left(T_{4} 295 \mathrm{~K} ; W_{6} 74 \% ; v_{2} 1.5 \mathrm{~m} / \mathrm{s}\right)$, and then in the oven at $T_{5}$ $373 \mathrm{~K}$ to the air-dry state with a mass fraction of moisture $W_{7}$ of $6.58 \%$.

The obtained pyrolyzed wood waste is an intermediate product with the characteristics of wood chips and porous carbon material at the same time, therefore, we determine the fractional composition due to the mass fraction of residue on sieves with holes with diameter: $d \geq 5.0 \cdot 10^{-3} \mathrm{~m}-63.8 \% ; 5.0 \cdot 10^{-3}>$ $>d \geq 3.6 \cdot 10^{-3} \mathrm{~m}-20.8 \% ; 3.6 \cdot 10^{-3}>d \geq 1.0 \cdot 10^{-3} \mathrm{~m}-11.9 \% ; d<1.0 \cdot 10^{-3} \mathrm{~m}$ (on the pallet) $-3.5 \%$. In the end, the working fraction of pyrolyzed wood waste with a diameter of $d \geq 5.0 \cdot 10^{-3}-63.8 \%$ was selected.

This may indicate that in the process of pyrolysis the largest fractions of wood chips with $d \geq 30 \cdot 10^{-3} \mathrm{~m}$ (mass fraction $0.8 \%$ ) and with $30 \cdot 10^{-3}>$ $>d \geq 20 \cdot 10^{-3} \mathrm{~m}$ (mass fraction 14\%) burn out the least and lose their weight and size (reduction of particle size - up to $60 \%$ ), with only $40 \%$ of the initial wood fractions in the form of pyrolyzed wood waste: wood chips fraction with $d \geq 30 \cdot 10^{-3} \mathrm{~m}$ is converted into pyrolyzed wood waste with $d \geq 12 \cdot 10^{-3} \mathrm{~m}$; wood chips fraction of $30 \cdot 10^{-3}>d \geq 20 \cdot 10^{-3} \mathrm{~m}$ is converted into pyrolyzed wood waste from $12 \cdot 10^{-3}>d \geq 8 \cdot 10^{-3} \mathrm{~m}$. The pyrolyzed wood waste of these two largest fractions in the fractionation process remains on the sieve $5.0 \cdot 10^{-3} \mathrm{~m}$.

The smallest fractions of wood chips from $10 \cdot 10^{-3}>d \geq 5 \cdot 10^{-3} \mathrm{~m}$ and from $d<5 \cdot 10^{-3} \mathrm{~m}$ - lose the most weight and size, burning out by $80 \%$ of the original size, and the pyrolyzed residue - up to $20 \%$, which during fractionation remains on the sieve $1.0 \cdot 10^{-3} \mathrm{~m}$ and the pallet. Wood chips fraction with $10 \cdot 10^{-3}>d \geq 5 \cdot 10^{-3} \mathrm{~m}$ is converted into pyrolyzed wood waste with $2 \cdot 10^{-3}>d \geq 1 \cdot 10^{-3} \mathrm{~m}$; wood chips fraction $d<5 \cdot 10^{-3} \mathrm{~m}-$ in pyrolyzed wood waste $d<1 \cdot 10^{-3} \mathrm{~m}$.

The average fraction of wood chips from $20 \cdot 10^{-3}>d \geq 10 \cdot 10^{-3} \mathrm{~m}$ in the process of pyrolysis burns out by $70 \%$, and the pyrolyzed residue - (up to $30 \%$ ) is distributed on three sieves with a diameter of holes: $5.0 \cdot 10^{-3} \mathrm{~m}$; $3.6 \cdot 10^{-3} \mathrm{~m} ; 1.0 \cdot 10^{-3} \mathrm{~m}$. The wood chips fraction of $20 \cdot 10^{-3}>d \geq 10 \cdot 10^{-3} \mathrm{~m}$ is converted into a pyrolyzed residue of $6 \cdot 10^{-3}>d \geq 3 \cdot 10^{-3} \mathrm{~m}-$ this is the most represented pyrolyzed the balance due to its mass share, which is $80 \%$.

Fig. 2 shows the appearance of wood chips and pyrolyzed wood waste at the main stages of wood preparation.

Fig. 3 shows the scheme of obtaining pyrolyzed wood waste. 


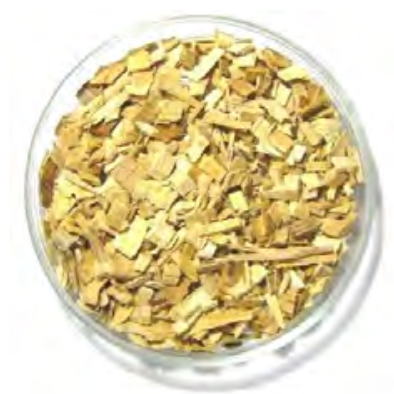

a

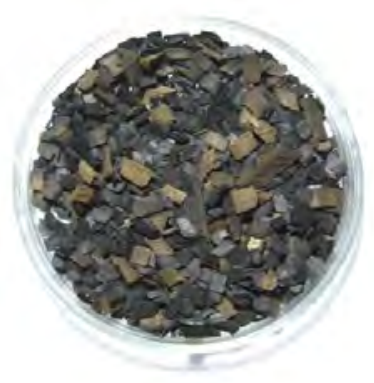

d

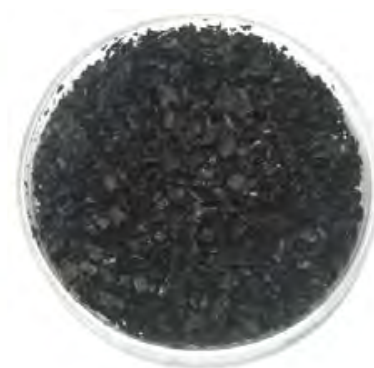

b

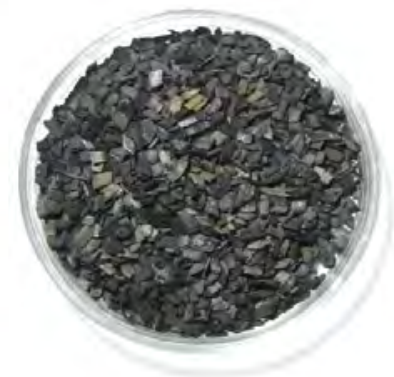

$\mathrm{e}$

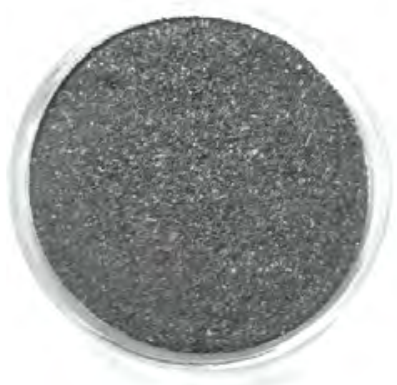

g

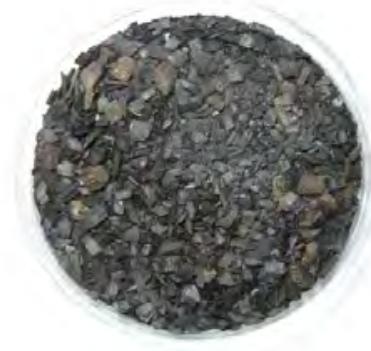

c

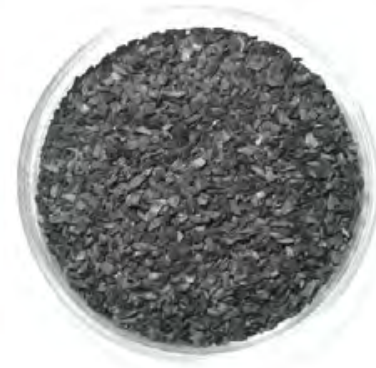

f

Fig. 2. Stages of obtaining pyrolyzed wood waste: a - oak chips $(6 \times 12 \times 3) \cdot$ $10^{-3} ; \mathrm{b}$ - pyrolyzed wood waste with a mass fraction of moisture $W_{4} 43.01 \%$; c-pyrolyzed wood waste after drying with a mass fraction of moisture $\boldsymbol{W}_{7}$ of $6.58 \% ; \mathrm{d}$ - pyrolyzed wood waste after fractionation with $d \geq 5.0 \cdot 10^{-3}$; e - pyrolyzed wood waste after fractionation with $5.0 \cdot 10^{-3}>d \geq 3.6 \cdot 10^{-3}$; f-pyrolyzed wood waste after fractionation with $3.6 \cdot 10^{-3}>\mathrm{d} \geq 1.0 \cdot 10^{-3}$; $\mathrm{g}$ - pyrolyzed wood waste after fractionation with $d<1.0 \cdot 10^{-3}$

\section{CONCLUSIONS}

Using the smallest particles - fractions with $d<1.0 \cdot 10^{-3}$ and $3.6 \cdot 10^{-3}>$ $>d \geq 1.0 \cdot 10^{-3}$ in the technology of production of wine and cognac products, cognac, whiskey, calvados there are certain difficulties: dusty structure pyrolyzed particles complicate the filtration process, so it makes it impossible to use these fractions.

The use of medium fractions with a diameter of $5.0 \cdot 10^{-3}>d \geq 3.6 \cdot 10^{-3}$ also makes it impossible to use these fractions, because in the structure of the pyrolyzed fraction of wood particles involved in the extraction - up to $10 \%$, while fully pyrolyzed particles involved in redox reactions and adsorption up to $90 \%$. 


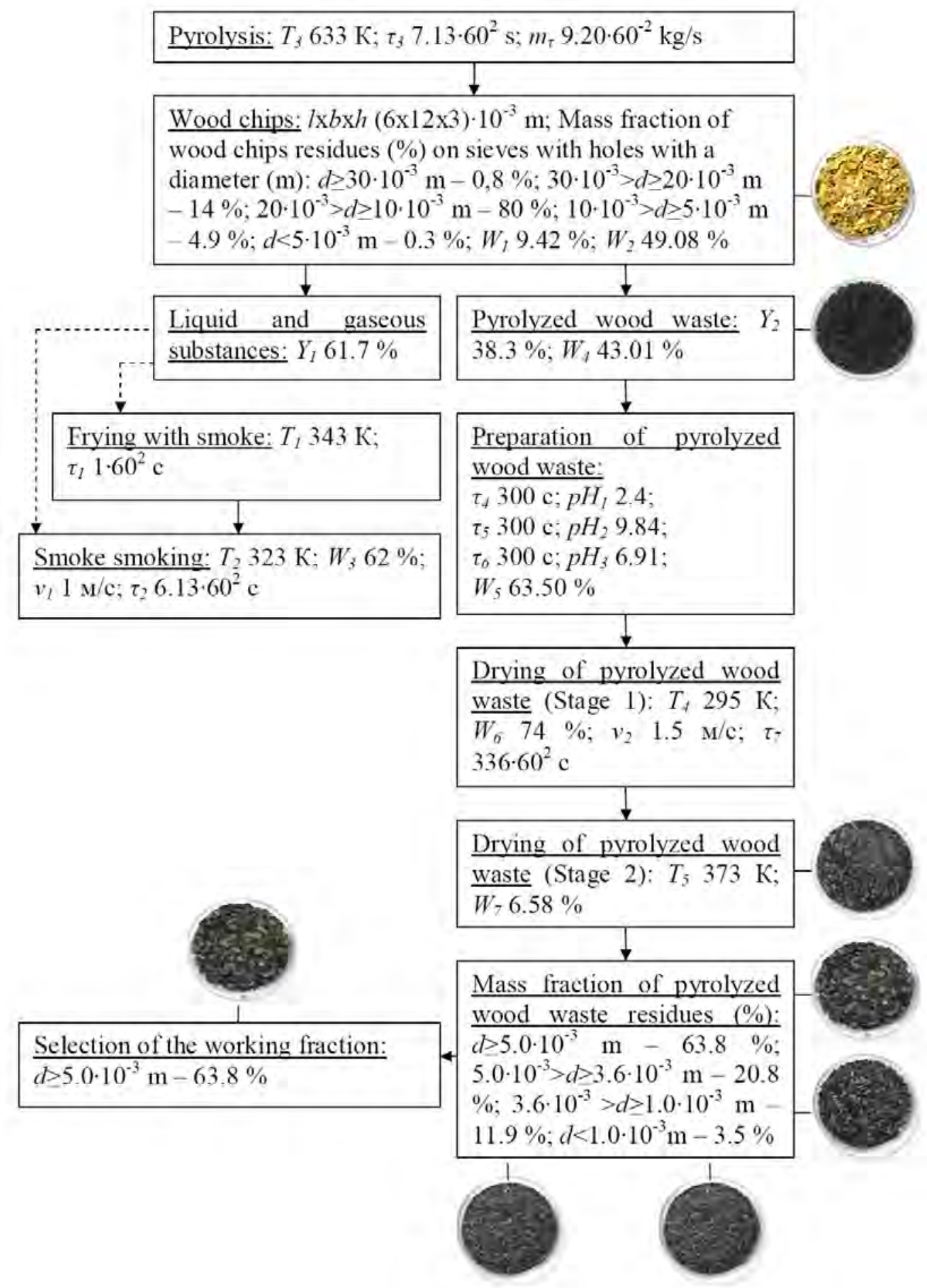

Fig. 3. General scheme for obtaining pyrolyzed wood waste

The use of the largest particles - fractions with $d \geq 5.0 \cdot 10^{-3}$ is promising in the technology of production of wine and cognac products, cognac, whiskey, calvados. In the structure of pyrolyzed wood chips involved in extraction - up to $60 \%$, with fully pyrolyzed particles involved in redox reactions and adsorption - up to $40 \%$. It should be used once, because after the first bookmark of wine and cognac products, cognac, whiskey, calvados, its 
surface layer is depleted of aromatic and phenolic substances, so further use of wood chips becomes inefficient.

Compared to traditional technology of aging wine and cognac products, cognac, whiskey, calvados in oak containers or enameled tanks with oak rivets, as well as when using crushed oak wood in the form of clapboards, chips, shavings, which are used repeatedly, pyrolyzed chips can be used only as additional chips raw materials when separated from the main raw material. The company individually selects the ratio of pyrolyzed wood chips to wood chips while improving organoleptic characteristics and stabilization of physical and chemical parameters of finished products.

\section{SUMMARY}

Due to the use of pyrolyzed wood waste from $d \geq 5.0 \cdot 10^{-3} \mathrm{~m}$ there is a reduction in the cost of used oak wood and intensification of the maturation of wine and cognac products, cognac, whiskey, calvados.

Thus, the method of production of pyrolyzed wood waste from oak, due to its single use, with minimal costs for raw materials and production, will intensify the maturation of wine and cognac products, cognac, whiskey, calvados, improve organoleptic characteristics and reduce their cost.

\section{REFERENCES}

1. Amorim C.D., Camilo A.G., de Oliveira C., Petenucci M.E., Fonseca G.G. Turning pork processing waste into value-added chemicals for the food industry. Sustainable Materials and Technologies. № 6. 2015. P. 1-5. DOI 10.1016/j.susmat.2015.09.001.

2. Barik D. Chapter 3: Energy Extraction From Toxic Waste Originating From Food Processing Industries. Energy from Toxic Organic Waste for Heat and Power Generation. 2019. P. 17-42. DOI 10.1016/B978-0-08-1025284.00003-1.

3. Bee S.L., Hamid Z.A.A. Hydroxyapatite derived from food industry biowastes: Syntheses, properties and its potential multifunctional applications. Ceramics International. № 46 (11). P. A1. 2020. P. 17149-17175. DOI 10.1016/j.ceramint.2020.04.103.

4. Fan H., Zhang M., Bhandari B., Yang C.H. Food waste as a carbon source in carbon quantum dots technology and their applications in food safety detection. Trends in Food Science \& Technology. № 95. 2020. P. 86-96. DOI 10.1016/j.tifs.2019.11.008.

5. Fujii H., Kondo Y. Decomposition analysis of food waste management with explicit consideration of priority of alternative management options and its application to the Japanese food industry from 2008 to 2015. Journal of Cleaner Production. № 1881. 2018. P. 568-574. DOI 10.1016/j.jclepro. 2018.03.241 
6. Galanakis C. 11: Food waste valorization opportunities for different food industries. The Interaction of Food Industry and Environment. 2020. P. 341-422. DOI 10.1016/B978-0-12-816449-5.00011-4.

7. Garcia-Garcia G., Stone J., Rahimifard S. Opportunities for waste valorisation in the food industry - A case study with four UK food manufacturers. Journal of Cleaner Production. 21120. 2019. P. 1339-1356. DOI 10.1016/j.jclepro.2018.11.269.

8. Garre A., Ruiz M.C., Hontoria E. Application of Machine Learning to support production planning of a food industry in the context of waste generation under uncertainty. Operations Research Perspectives. № 7. 2020. DOI 10.1016/j.orp.2020.100147.

9. Hall G.M., Howe J. Energy from waste and the food processing industry. Process Safety and Environmental Protection. № 90 (3). 2012. P. 203-212. DOI 10.1016/j.psep.2011.09.005.

10. Kuzmin O., Shendrik T. Prospective assessment of the use of the carbonized wood waste of food industry for the production of activated carbon. Food Science for Well-being (CEFood 2016) : 8th Central European Congress on Food., Kyiv, 23-26 May 2016. Kyiv, 2016. P. 109.

11. Kuzmin A., Kuzmin O., Shendrik T. Obtaining and properties of active charcoal from pyrolized wood waste. Chemical Technology and Engineering : 2nd International Scientific Conference, Lviv, 24-28 June 2019. Lviv, P. 87-89.

12. Kuzmin O., Shendrik T., Zubkova V. Substantiation of the conditions of obtaining porous carbon materials from pyrolyzed wood wastes by chemical activation of $\mathrm{H}_{3} \mathrm{PO}_{4}$. Ukrainian Food Journal. 2017. № 6 (1). P. 103-116. DOI 10.24263/2304-974X-2017-6-1-12.

13. Kuzmin O., Tamarkina J., Shendrik T., Zubkova V., Koval O., Roman T. Production of active coal from pyrolyzed wood wastes by alkaline activation of KOH. Ukrainian Food Journal. 2017. № 6 (3). P. 443-458. DOI 10.24263/2304-974X-2017-6-3-5.

14. Landin-Sandoval V.J., Mendoza-Castillo D.I., Bonilla-Petriciolet A., Aguayo-Villarreal I.A., Gonzalez-Ponce H.A. Valorization of agri-food industry wastes to prepare adsorbents for heavy metal removal from water. Journal of Environmental Chemical Engineering. № 8 (5). 2020. DOI 10.1016/j.jece.2020.104067.

15. Lang L., Wang Y., Chen X., Zhang Z., Han W. Awareness of food waste recycling in restaurants: evidence from China. Resources, Conservation and Recycling. № 161. 2020. DOI 10.1016/j.resconrec.2020.104949

16. Martin-Rios C., Demen-Meier C., Gцssling S., Cornuz C. Food waste management innovations in the foodservice industry. Waste Management. № 79. 2018. P. 196-206. DOI 10.1016/j.wasman.2018.07.033. 
17. Mo W.Y., Man Y.B., Wong M.H. Use of food waste, fish waste and food processing waste for China's aquaculture industry: Needs and challenge. Science of The Total Environment. 613-6141. 2018. P. 635-643. DOI 10.1016/j.scitotenv.2017.08.321

18. Okumus B., Taheri B., Giritlioglu I., Gannon M.J. Tackling food waste in all-inclusive resort hotels. International Journal of Hospitality Management. № 88. 2020. DOI 10.1016/j.ijhm.2020.102543.

19. Pantaleo A.M., Fordham J., Oyewunmi O.A., De Palma P., Markides C.N. Integrating cogeneration and intermittent waste-heat recovery in food processing: Microturbines vs. ORC systems in the coffee roasting industry. Applied Energy.№ 2251. 2018. P. 782-796. DOI 10.1016/ j.apenergy. 2018.04.097

20. Schaub S.M., Leonard J.J. Composting: An alternative waste management option for food processing industries. Trends in Food Science \& Technology. № 7 (8). 1996. P. 263-268 DOI 10.1016/0924-2244(96)10029-7.

21. Singh R.S., Kaur N., Kennedy J.F. Pullulan production from agroindustrial waste and its applications in food industry: A review. Carbohydrate Polymers. № 2171. 2019. P. 46-57. DOI 10.1016/j.carbpol.2019.04.050

22. Tavill G. Industry challenges and approaches to food waste. Physiology \& Behavior. № 2231. 2020. DOI 10.1016/j.physbeh.2020.112993.

23. Tekler Z.D., Low R., Chung S.Y., Low J.S.C., Blessing L. A Waste Management Behavioural Framework of Singapore's Food Manufacturing Industry using Factor Analysis. Procedia CIRP. № 80. 2019. P. 578-583. DOI 10.1016/j.procir.2019.01.066.

24. Vivas N. Manuel de tonnellerie a l'usage des utilisateurs de futaille. Editions Feret. Bordeaux. 2002. 207 p.

25. Wiel B.Z., Weijma J., Middelaar C.E., Kleinke M., Wichern F. Restoring nutrient circularity: A review of nutrient stock and flow analyses of local agro-food-waste systems. Resources, Conservation and Recycling. № 160. 2020. DOI 10.1016/j.resconrec.2020.104901.

26. Кузьмин О.В., Тамаркина Ю.В., Шендрик Т.Г. Перспективы использования древесных отходов пищевой промышленности для получения адсорбентов. Актуальные вопросы охраны окружающей среды и обеспечения экологической безопасности промышленных регионов : материалы междунар. науч.-практ. конф., г. Кемерово, 3-4 октябр. 2017 г. Кемерово, 2017. С. 295-301.

27. Кузьмин О.В., Королесова В.Г. Стабилизащия вина в прочессе хранения. Актуальные проблемы современного товароведения : матер. междунар. научн.-практ. конф., г. Гомель, 18-19 нояб. 2010 г., Гомель, 2010. C. 89.

28. Луканин А., Зражва С. Сушка и созревание дубовой клепки. Напитки. Технологии. Инновачии. 2013. № 8. С. 82-83. 
29. Луканін О.С., Тимчик О.В., Зражва С.Г. Мікробіологічна оцінка деревини дуба різних регіонів України. Агроекологічний журнал. 2008. № 3. C. 157-160.

30. Луканін О.С., Сидоренко О.М., Феодосіді К.Ф. Продукти переробки дуба, або ефект «нової бочки», при витримці вин та коньячних спиртів. Сучасні напрями розвитку технологї алкогольних $i$ безалкогольних напоїв : I міжнар. наук.-практ. конф. м. Київ, 2006 p. Київ, 2006. С. 4-11.

31. Луканін О.С., Сидоренко О.М. Критерії визначення віку коньячних спиртів. Вісник аграрної науки. 2016. № 10. С. 51-60.

32. Луканін О.С. Ефект нової бочки. Виноград $і$ вино. 2002. № 5. C. $20-23$.

33. Оганесянц Л.А. Дуб и виноделие. Москва : Пищевая промышленность, $1998.256 \mathrm{c}$.

34. Рекомендації щодо технології висушування-дозрівання дубової клепки для винних, коньячних та кальвадосних бочок / Луканін О. С. та ін. Київ : Інститут агроекології і природокористування НААН, 2010. $56 \mathrm{c}$.

35. Сборник технологических инструкций, правил и нормативных материалов по винодельческой промышленности / под ред. Г.Г. Валуйко. Москва : Агропромиздат, 1985. 512 с.

36. Скурихин С.М. Химия коньяка и бренди. Москва : ДеЛи Принт, 2005. $296 \mathrm{c}$.

37. Спосіб виробництва активного вугілля із карбонізату деревини: пат. 102942 Україна, МПК С01В 31/10. № u201505202; заяв. 27.05.2015; опубл. 25.11.2015, Бюл. № 22.

38. Спосіб виробництва активного вугілля із карбонізату деревини: пат. 112819 Україна: МПК С01В 31/08. № а201505195; заяв. 27.05.2015; опубл. 25.10.2016, Бюл. № 20.

39. Спосіб виробництва дубової мікроклепки : пат. 8047 Україна : МПК C12G 3/07. № u200500127 ; заявл. 05.01.2005; опубл. 15.07.2005, Бюл. № 7.

40. Спосіб виробництва піролізованої тріски: пат. 102045 Україна: МПК С12G 3/07. № u201504113; заяв. 28.04.2015; опубл. 12.10.2015, Бюл. № 19.

41. Спосіб виробництва пористих вуглецевих матеріалів із піролізованих деревних відходів: пат. 103581 Україна: МПК С01В 31/08. № u201505455; заяв. 03.06.2015; опубл. 25.12.2015, Бюл. № 24.

42. Спосіб лікування хвороби вина «мишачий тон»: пат. 72724A Україна, МПК С12G 3/07, С12Н 1/02. № 20031213183; заяв. 30.12.2003; опубл. 15.03.2005, Бюл. № 3. 
43. Спосіб обробки деревини дуба для одержання піролізованої тріски: пат. 115673 Україна: МПК С12G 3/07, С12Н 1/22, А23В 4/044. № a201504104; заяв. 28.04.2015; опубл. 11.12.2017, Бюл. № 21.

44. Спосіб обробки подрібненої деревини дуба : пат. 50046А Україна, МПК С12G 3/07. № 2001031730; заявл. 15.03.2001; опубл. 15.10.2002, Бюл. № 10.

45. Удосконалення технології висушування-дозрівання дубової клепки / Луканін О.С., Байлук С.І., Зражва С.Г., Агафонов М.Ф. Вісник аграрної науки. 2010. № 12. С. 52-55.

\section{Information about authors:}

Kuzmin O. V.,

Candidate of Technical Sciences, Associate Professor at the Department of Technology of Restaurant and Ayurvedic Products National University of Food Technologies 68, Volodymyrska str., Kyiv, 01601, Ukraine Isaienko V. M.,

Candidate of Technical Sciences, Doctor of Biological Sciences, Professor, Rector

National Aviation University 1, Liubomyra Huzara ave., Kyiv, 03058, Ukraine 